Original Article

\title{
Arbuscular mycorrhizal fungi activity in the rhizosphere of tree seedlings subjected to residual herbicides
}

\author{
Atividade de fungos micorrízicos arbusculares na rizosfera de mudas de árvores \\ submetidas a herbicidas residuais
}

\author{
Edson Aparecido dos Santos ${ }^{\mathrm{a}}$ (D), Uelson Sabino da Silva-Filho ${ }^{\mathrm{a}}$ (D), Gabriela Madureira Barroso ${ }^{\mathrm{b*}}$ (D), \\ Jordana Stein Rabelo ${ }^{\mathrm{a}}$ (D), Edmar Isaías de Meloc (D) and José Barbosa dos Santos ${ }^{\mathrm{d}}$ (D) \\ aUniversidade Federal de Uberlândia - UFU, Instituto de Ciências Agrárias, Monte Carmelo, MG, Brasil \\ bUniversidade Federal dos Vales do Jequitinhonha e Mucuri - UFVJM, Departamento de Engenharia Florestal, Diamantina, MG, Brasil \\ 'Universidade Federal de Uberlândia - UFU, Instituto de Química, Monte Carmelo, MG, Brasil \\ dUniversidade Federal dos Vales do Jequitinhonha e Mucuri - UFVJM, Departamento de Agronomia, Diamantina, MG, Brasil
}

\begin{abstract}
Trees occurring on the margins of agricultural areas can mitigate damage from residual herbicides. Rhizospheric microbial activity associated with trees is one of the main remedial capacity indicators. The objective of this study was to evaluate the rhizospheric microbiological activity in tree species subjected to the herbicides atrazine and sulfentrazone via the rhizosphere. The experiment was designed in four blocks and a $6 \times 3$ factorial scheme. The first factor consisted of six tree species from Brazil and the second of atrazine, sulfentrazone, and water solutions. Four herbicide applications were performed via irrigation. The total dry mass of the plants, mycorrhizal colonization, number of spores, basal respiration of the rhizospheric soil, and survival rate of bioindicator plants after phytoremediation were determined. Trichilia hirta had higher biomass when treated with atrazine and sulfentrazone. Herbicides decreased the microbial activity in Triplaris americana and did not affect the microbiological indicators of Myrsine gardneriana, Schizolobium parahyba, and Toona ciliata. Fewer bioindicator plants survived in soil with Triplaris americana and sulfentrazone. Microbiological indicators were influenced in different ways between species by the presence of herbicides in the rhizosphere.
\end{abstract}

Keywords: microbial activity, atrazine, sulfentrazone, basal respiration, rhizoremediation.

\begin{abstract}
Resumo
As árvores que ocorrem nas margens das áreas agrícolas podem mitigar os danos dos herbicidas residuais. A atividade microbiana rizosférica associada às árvores é um dos principais indicadores de capacidade corretiva. $\mathrm{O}$ objetivo deste trabalho foi avaliar a atividade microbiológica rizosférica em espécies arbóreas submetidas aos herbicidas atrazina e sulfentrazone via rizosfera. 0 experimento foi estruturado em quatro blocos e esquema fatorial $6 \times 3.0$ primeiro fator consistiu em seis espécies de árvores do Brasil e o segundo em soluções de atrazine, sulfentrazone e água. Quatro aplicações de herbicidas foram realizadas via irrigação. Foram determinados a massa seca total das plantas, colonização micorrízica, número de esporos, respiração basal do solo rizosférico e taxa de sobrevivência de plantas bioindicadoras após fitorremediação. Trichilia hirta apresentou maior biomassa quando tratada com atrazina e sulfentrazone. Os herbicidas diminuíram a atividade microbiana em Triplaris americana e não afetaram os indicadores microbiológicos de Myrsine gardneriana, Schizolobium parahyba e Toona ciliata. Menos plantas bioindicadoras sobreviveram no solo com Triplaris americana e sulfentrazone. Os indicadores microbiológicos foram influenciados de formas distintas entre as espécies pela presença dos herbicidas na rizosfera.
\end{abstract}

Palavras-chave: atividade microbiana, atrazine, sulfentrazone, respiração basal, rizorremediação.

\section{Introduction}

Residual herbicides such as atrazine and sulfentrazone are very important in agriculture. Residual herbicides remain active in the soil for months after application, thereby controlling plants for a convenient period (Shaner, 2014). These products are applied to soybean, corn, sugar cane, eucalyptus, pine, cotton, etc. These crops account for approximately 70 million ha in Brazil and are commonly bordered by forests, permanent preservation areas, reserves, or riparian forests (Martinelli et al., 2010; Zalles et al., 2019). Atrazine and sulfentrazone residues have already been found in areas close to crops, especially in water bodies (Santos et al., 2015; Thorngren et al., 2017). 
Atrazine is an inhibitor of photosystem II, has low adsorption to soil particles, variable persistence (Barchanska et al., 2014), and a high potential for contaminating water courses (Sequinatto et al., 2013). It is the main pesticide contaminant in aquifers worldwide (Benvenuto et al., 2010). Sulfentrazone is an inhibitor of the enzyme protoporphyrinogen oxidase (Dayan and Watson, 2011), and its main characteristics are that it has a halflife of over 500 days and low soil sorption. It is classified as extremely dangerous for the surface and groundwater (Gustafson, 1989; Passos et al., 2013). Therefore, these products can be dangerous to the environment, causing problems especially close to the application areas.

Phytoremediation is an alternative used to reduce the harmful effects of herbicides in areas adjacent to crops. This practice utilizes plants and their associated microbiome to remove, decrease, or immobilize herbicides (Cao et al., 2018; Rainbird et al., 2018). The use of trees for the phytoremediation of areas with herbicide residues has become a topic of interest in agriculture (Cabral et al., 2017; Santos et al., 2018; Gómez et al., 2019). Trees are essential for the protection of water bodies, areas sensitive to erosion, and fauna. Trees also act as natural filters and increase the retention of herbicides in the subsoil next to the rhizospheres (Chellaiah and Yule, 2018).

The role of the rhizosphere microorganism community is important in the phytoremediation process, as the main means of degrading herbicides in the soil is through microbial activity (Peterson et al., 2016; Parte et al., 2017) and biological processes such as phytostimulation or rhizodegradation (Rainbird et al., 2018). In these processes, exudates released by plants stimulate microbial activity that degrades herbicides. Mycorrhizal fungi are important microsymbionts that have a stimulating effect on plant growth and can help with soil bioremediation (Treu and Falandysz, 2017). Plants provide fungi with carbon compounds, while fungi benefit their hosts by causing greater absorption of nutrients and water, in addition to promoting moisture retention and aggregation as well as soil stability (Smith and Smith, 2012). Some indicators of microbial activity in the soil, such as that of mycorrhizal fungi, are obtained through spore counting, root colonization, and baseline respiration values (Anderson and Domsch, 2010).

Trees that occur marginally to crops in Brazil are therefore responsible for mitigating the harmful effects of residual herbicides when they move in the soil and reach non-target areas. In this sense, the microbiological indicators of the roots of these trees must be evaluated in view of the residual herbicides. Species with better responses to rhizospheric microbiological indicators can be recommended when planting in areas adjacent to crops. However, there are few studies involving the effects of herbicides on the rhizosphere of native trees that could be used for phytoremediation. Therefore, the objective of this study was to evaluate the rhizospheric microbiological activity in tree species subjected to the herbicides atrazine and sulfentrazone via the rhizosphere.

\section{Materials and Methods}

The work was developed in a greenhouse and laboratories at the Institute of Agricultural Sciences, at the Federal University of Uberlândia, in Monte Carmelo, MG, Brazil.

\subsection{Growth of seedlings in soil with herbicides}

The experiment was designed in four blocks and a factorial scheme $(6 \times 3)$, totaling 18 trees per treatment (tree / herbicide combination). The first factor consisted of six tree species (see Table 1) and the second of solutions of atrazine, sulfentrazone, and just water (control). The control treatment consisted of trees maintained without herbicide application.

Seedlings between $15-20 \mathrm{~cm}$ high were used. Within the same species, all were equal in terms of matrix, height, age, and number of leaves. The seedlings were transplanted into pots with a capacity of $20 \mathrm{dm}^{3}$ filled with substrate containing soil chemically and physically characterized (see Table 2). The soil used as substrate was collected from an area with no history of herbicide application at a depth of $0-20 \mathrm{~cm}$. The material was homogenized and placed in the vessels.

The vessels had a perforated bottom (10 holes, each $5 \mathrm{~mm}$ in diameter) and were placed on $60 \mathrm{~mm}$ tall containment dishes. The seedlings were transplanted to the pots where they remained for 60 days for acclimatization. The irrigation was carried out considering the uniformity of the soil that was maintained at $70 \%$ of the field capacity, until the end of the experiment.

After 60 days of acclimatization, the herbicides were applied. The dose (atrazine: 4,000 $\mathrm{g} \mathrm{ha}^{-1}$; sulfentrazone:

Table 1. Characterization of the tree species studied.

\begin{tabular}{lcc}
\hline \multicolumn{1}{c}{ Species } & Popular name & Main uses \\
\hline Inga edulis Mart. & Ingá & Forestry restoration \\
Myrsine gardneriana A.DC. & Pororoca & Forestry restoration \\
Schizolobium parahyba (Vell.) Blake & Guapuruvu & Forestry restoration / silviculture \\
Toona ciliata M. Roem. & Cedro & Forestry restoration / silviculture \\
Trichilia hirta L. & Pompéia & Forestry restoration \\
Triplaris americana L. & Pau-formiga & Forestry restoration \\
\hline
\end{tabular}

Source: Flora do Brasil (JBRJ, 2020). 
Table 2. Chemical and physical properties of the soil used as substrate for seedling cultivation in sampling performed at the time of transplanting. Classification: Typical Dystrophic Red Latosol. Collection place: $18^{\circ} 43^{\prime} 43^{\prime \prime}$ S and $47^{\circ} 31^{\prime} 35^{\prime \prime}$ W.

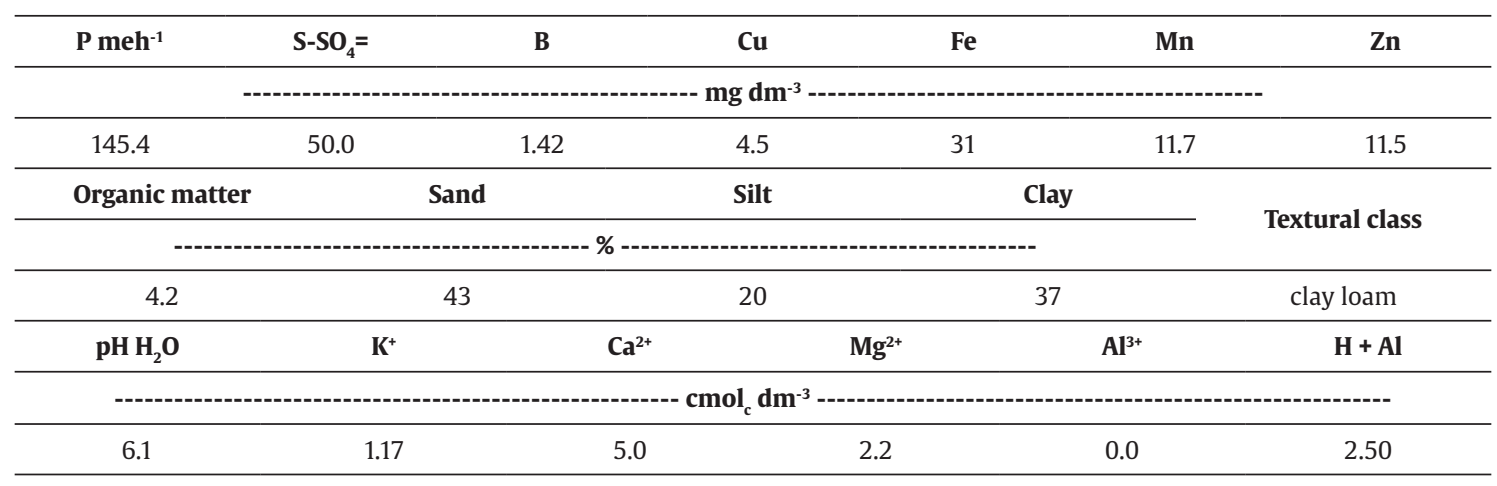

$600 \mathrm{~g} \mathrm{ha}^{-1}$ ) was divided into four applications performed at 30-day intervals; each application corresponded to one fourth of the commercial dose. The dose was fractionated to simulate herbicide transport by rainwater. The final concentrations were calculated according to the area of the vessel and the sub-irrigation applications. The herbicides were diluted in $200 \mathrm{~mL}$ of water, and the solution was placed in the containment dishes positioned below each unit. The solution was readily absorbed by the soil, simulating the arrival of the herbicides via the subsoil.

One hundred twenty days after the first herbicide application, the plants were removed from the pots, and the total dry mass (leaves, branches, and roots) was determined. For this, a forced air circulation oven was used, at $65{ }^{\circ} \mathrm{C}$, until a constant weight was reached.

\subsection{Determination of mycorrhizal colonization, number of spores, and basal respiration of rhizospheric soil}

For the determination of mycorrhizal colonization, number of spores, and basal respiration of rhizospheric soil, four replications were also used, totaling 72 samples for each tree / herbicide combination (six tree species, two herbicide treatments and a control).

The roots were collected at the end of the experiment and preserved in a solution of formaldehyde, acetic acid, and ethyl alcohol. The roots were washed, placed in biopsy cassettes, and immersed in $10 \% \mathrm{KOH}$. They were then heated to $60{ }^{\circ} \mathrm{C}$ in $10 \% \mathrm{KOH}$ for $10 \mathrm{~min}$ for clarification, washed with distilled water, and immersed in $15 \% \mathrm{H}_{2} \mathrm{O}_{2}$ for $10 \mathrm{~s}$. The fungal structures were stained for $3 \mathrm{~min}$ at $90{ }^{\circ} \mathrm{C}$ in a solution with Parker ${ }^{\circledR} 5 \%$ commercial pen ink, 5\% acetic acid, and $10 \%$ lactoglycerol. The arbuscular mycorrhizal fungi were determined based on the methodology proposed by Vierheilig et al. (1998). Four microscopy slides were prepared containing 10 root segments, each measuring $1 \mathrm{~cm}$, to examine under an optical microscope. We assigned scores from 0 to 100 according to the occupation of the root area by fungal structures (Bethlenfalvay et al., 1981).
To extract the spores, $50 \mathrm{~g}$ of rhizospheric soil was washed and sieved through $0.71 \mathrm{~mm}$ and $0.053 \mathrm{~mm}$ meshes. The material retained in the $0.053 \mathrm{~mm}$ mesh sieve was centrifuged for $3 \mathrm{~min}$ at 1,500 rpm. A 70\% sucrose solution was added. The sediment material was stirred to suspend the spores in the solution. Then, centrifugation was performed for $2 \mathrm{~min}$ at $700 \mathrm{rpm}$. The supernatant was passed through a $0.053 \mathrm{~mm}$ sieve, and the retained material was transferred to a fluted plate for spore counting under a stereomicroscope (Gerdemann and Nicolson, 1963).

To quantify basal respiration, $10 \mathrm{~g}$ of soil was separated to determine the dry soil mass. The humidity of the samples was standardized to $60 \%$ of the field capacity with distilled water. One hundred grams of moist soil was transferred to a glass jar with an airtight lid. Next to the soil, inside the flask, a test tube containing $15 \mathrm{~mL}$ of standardized $0.5 \mathrm{~N} \mathrm{NaOH}$ was placed to capture the $\mathrm{CO}_{2}$ produced. Another test tube containing $10 \mathrm{~mL}$ of distilled water was used to maintain the humidity inside the flask. The vials were closed and incubated at $25{ }^{\circ} \mathrm{C}$ for one week. Finally, $1 \mathrm{~mL}$ of $\mathrm{BaCl}_{2}$ (50\%) and 2 drops of phenolphthalein were added to the $\mathrm{NaOH}$ solution in the tubes. We performed titration of the excess $\mathrm{NaOH}$ with $0.5 \mathrm{~N} \mathrm{HCl}$ and indirect determination of $\mathrm{CO}_{2}$ from the soil (Silva et al., 2007).

\subsection{Estimation of herbicide residues in soil}

To estimate the herbicide residue in the soil, the bioassay was used.When the plants were removed from the pots, $200 \mathrm{~g}$ of soil was extracted from the roots, homogenized, and sieved. This soil remained on a laboratory bench for 3 days until a constant weight was reached. An amount of $150 \mathrm{~g}$ was placed in pots $(200 \mathrm{~mL})$ in the same factorial scheme as the one used for the greenhouse. Five cucumber seeds (Cucumis sativus L.) (bioindicator) were sown in each pot. After germination, the seedlings were thinned seven days after sowing, keeping three plants per pot. The soil was maintained at $70 \%$ of the field capacity, and each pot was evaluated for the number of live plants 14 days after sowing.

\subsection{Statistical analysis}

The values of the analyzed variables were transformed into percentages in comparison to the control treatment 
(without herbicide) for standardization, as they are different species (Santos et al., 2020).

The assumptions of homogeneity of variance and normality of residuals were tested using the Shapiro-Wilk and O'Neill-Mathews tests, respectively. Subsequently, the data were subjected to analysis of variance, differentiated by Tukey's test for treatments with herbicides, and grouped according to Scott-Knott's criterion for the species factor; the significance level was set at $5 \%$ for both tests. The data from trees with and without herbicides were also subjected to multivariate analysis, ordered by non-metric multidimensional scaling (NMDS) (Clarke, 1993) and 2D representation using the Bray-Curtis similarity matrix for similarity analysis (Culman et al., 2008). NMDS stress values greater than 0.2 suggest a weaker representation and are difficult to interpret (Blaud et al., 2015), in which case two dimensions may not be sufficient to accurately reflect the differences if the data structure is complex (Schütte et al., 2008).

\section{Results}

We performed tests to assess the normality of the residues and the homogeneity of variances. The total dry mass of Trichilia hirta was higher in treatments containing atrazine and sulfentrazone. The herbicides decreased the total biomass of Triplaris americana. The species exhibited different behavior in terms of biomass allocation under the herbicide treatments. Schizolobium parahyba and $T$. americana were the most affected and T. hirta was the one that developed the best when exposed to atrazine. Triplaris americana was the most sensitive to sulfentrazone (see Figure 1).

The rhizospheric colonization by mycorrhizal fungi was higher in the treatment containing sulfentrazone for Inga edulis and lower for Myrsine gardneriana, Toona ciliata, and T. hirta, compared to the control treatment. Inga edulis and T. hirta had decreased colonization in the presence of atrazine compared to the treatment without the herbicide. The species exhibited differential behavior for this variable as a result of the atrazine and sulfentrazone treatments, with $I$. edulis, M. gardneriana, S. parahyba, and T. americana, standing out the most in soil contaminated with atrazine; I. edulis stood out in the soil contaminated with sulfentrazone (see Figure 2).

Herbicides did not influence the spore count of rhizospheric fungi in forest species. However, there were differences among the species that were treated with atrazine. The species with the highest sporulation were I. edulis, T. ciliata, and T. hirta (see Figure 3).

The basal soil respiration was lower in the treatment containing sulfentrazone in the rhizosphere of T. hirta and in the treatment containing atrazine in the rhizosphere of T. americana. The basal respiration of the other species' rhizospheric soil was not influenced by herbicides. Regarding the differences among species, the plants exhibited the same behavior as those under the atrazine herbicide treatment. However, when the contaminant was sulfentrazone, I. edulis, M. gardneriana, and T. americana released higher amounts of $\mathrm{CO}_{2}$ from the rhizospheric soil sample (see Figure 4).

The non-metric multidimensional scaling showed a stress value of less than 0.2 . There was a strong grouping of results for all tree species that were not treated with herbicides. In addition, there was a tendency to group the behavior of all species in the control treatment with that of M. gardneriana, S. parahyba, and T. ciliata treated with

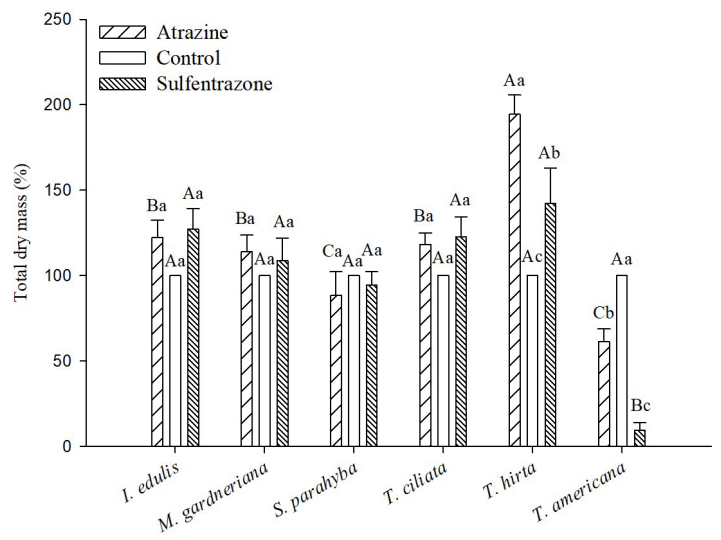

Figure 1. Percentage of total dry mass in relation to the control treatment of seedlings of forest trees species subjected to the herbicides atrazine and sulfentrazone via sub-irrigation. Averages followed by the same lowercase letter do not differ by Tukey's test at $5 \%$ significance for the herbicidal factor. Means followed by the same capital letter do not differ according to the Scott-Knott grouping criterion at $5 \%$ significance for the species. CV (Coefficient of variation $)=18.3 \%$.

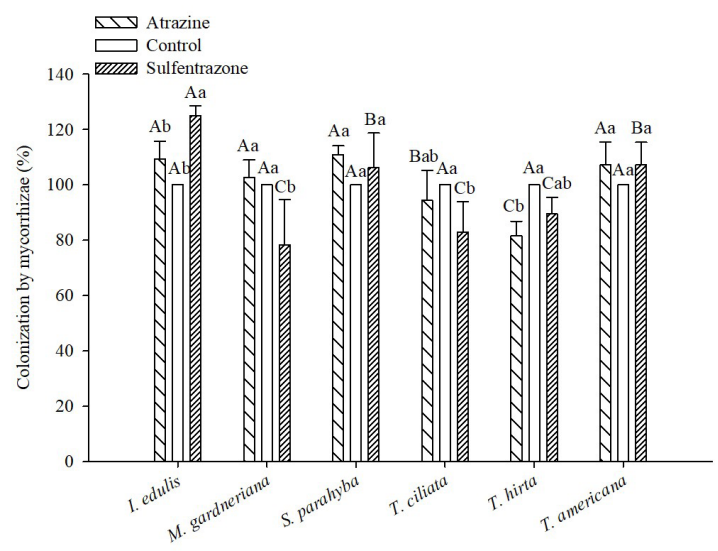

Figure 2. Percentage of rhizospheric colonization by mycorrhizae in relation to the control treatment of seedlings of forest trees species subjected to the herbicides atrazine and sulfentrazone via sub-irrigation. Averages followed by the same lowercase letter do not differ by Tukey's test at $5 \%$ significance for the herbicidal factor. Means followed by the same capital letter do not differ according to the Scott-Knott grouping criterion at 5\% significance for the species. CV (Coefficient of variation $)=8.93 \%$. 


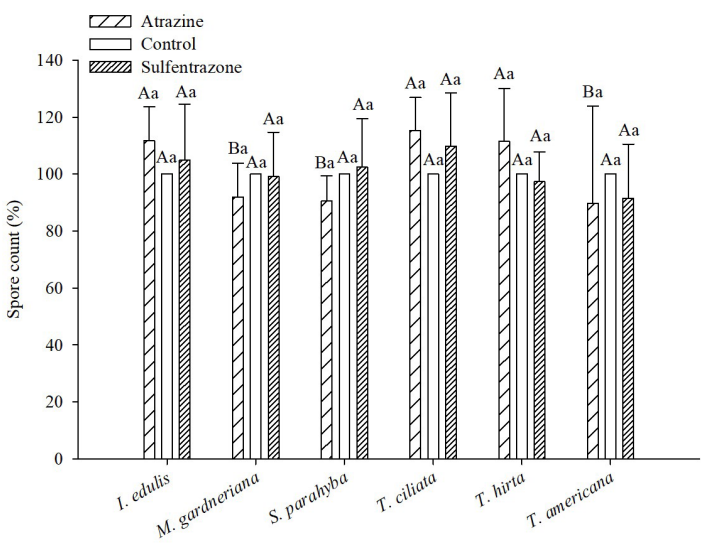

Figure 3. Spore count percentage in relation to the control treatment of seedlings of forest trees species subjected to the herbicides atrazine and sulfentrazone via sub-irrigation. Averages followed by the same lowercase letter do not differ by Tukey's test at $5 \%$ significance for the herbicidal factor. Means followed by the same capital letter do not differ according to the Scott-Knott grouping criterion at $5 \%$ significance for the species. CV (Coefficient of variation $)=10.96 \%$.

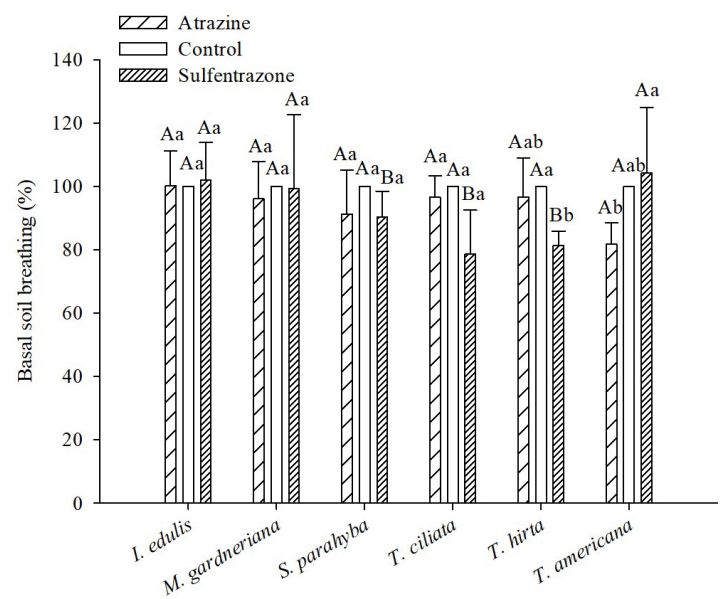

Figure 4. Percentage of basal soil respiration in relation to the control treatment of seedlings of forest tree species subjected to the herbicides atrazine and sulfentrazone via sub-irrigation. Averages followed by the same lowercase letter do not differ by Tukey's test at $5 \%$ significance for the herbicidal factor. Means followed by the same capital letter do not differ according to the Scott-Knott grouping criterion at 5\% significance for the species. $\mathrm{CV}($ Coefficient of variation $)=11.63 \%$.

atrazine and that of S. parahyba and T. ciliata treated with sulfentrazone (see Figure 5).

In the bioassay, the average number of live cucumber plants in soil with atrazine was lower in the area where $T$. hirta was grown than in the area where T. ciliata was grown. The cultivation of T. hirta and T. americana in soil with sulfentrazone also promoted a decrease in the number of cucumber plants (see Table 3).

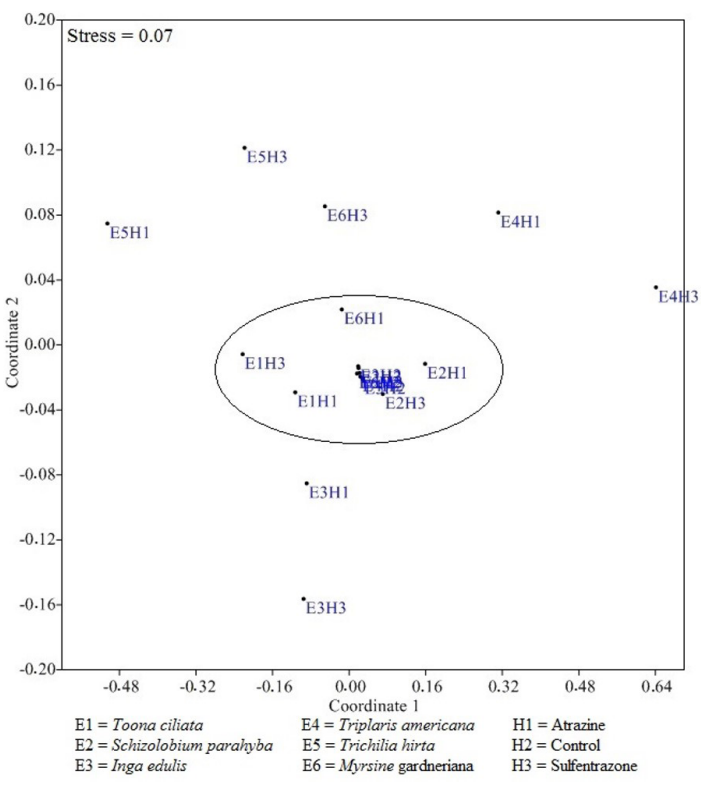

Figure 5. Non-metric multidimensional ordering (NMDS) of tree species treated with herbicides and control was performed for all analyzed variables of the tree species.

\section{Discussion}

Arbuscular mycorrhizal fungi (AMFs) are the primary biotic components of the soil and mandatory symbionts of plants. Carbohydrates and mineral nutrients are exchanged within the roots through the plant and fungus interface (Berruti et al., 2016). AMFs are directly related to the colonization processes of many trees, as they reduce the negative impact of the lack of nutrients (Nouri et al., 2014) and contribute to the phytoremediation of pollutants (Joner and Leyval, 2009). However, herbicides can cause negative effects on the mycorrhizal fungi community, reducing spore production and root colonization, for example (Druille et al., 2013). The disturbances that occur in the soil cause changes in baseline breathing, and the resilience of the group of microorganisms is directly related to the plant species in the area (Vosátka et al., 2006). In the present study, the responses of microbiological indicators to herbicides were related to the products and tree species used. Although the variables mycorrhizal colonization and number of spores are specific to mycorrhizal fungi, $\mathrm{CO}_{2}$ emissions result from the entire microbial community in the soil.

The greater accumulation of dry mass in T. hirta treated with herbicides could be due to the hormone effect, which is a differential response of some plants to herbiside underdosing (Belz and Duke, 2014). The applications were made fractionally and the herbicide's behavior was influenced by the physical and chemical characteristics of the soil. Hormone behavior has been reported for several herbicides such as tebuthiuron, glyphosate, glufosinate ammonium, and 2,4-D in several plant species (Dragićević et al., 2013; Ather Nadeem et al., 2017; Faria et al., 2018). 
Table 3. Number of live cucumber (Cucumis sativus L.) plants grown on the rhizospheric soil of trees subjected to residual herbicides.

\begin{tabular}{lccc}
\hline \multirow{2}{*}{ Species } & \multicolumn{2}{c}{ Number of live plants after 14 days of cultivation } \\
\cline { 2 - 4 } & atrazine & no herbicide & sulfentrazone \\
\hline Inga edulis & $2.00 \pm 0.82 \mathrm{ABa}$ & $2.50 \pm 1.00 \mathrm{Aa}$ & $2.25 \pm 0.50 \mathrm{Aa}$ \\
Myrsine gardneriana & $1.75 \pm 0.96 \mathrm{ABa}$ & $2.50 \pm 0.58 \mathrm{Aa}$ & $1.75 \pm 0.50 \mathrm{Aa}$ \\
Schizolobium parahyba & $2.00 \pm 0.82 \mathrm{ABa}$ & $2.00 \pm 0.82 \mathrm{Aa}$ & $2.00 \pm 0.82 \mathrm{Aa}$ \\
Toona ciliata & $2.50 \pm 0.58 \mathrm{Aa}$ & $1.50 \pm 0.58 \mathrm{Aa}$ & $1.75 \pm 0.96 \mathrm{ABa}$ \\
Trichilia hirta & $1.00 \pm 0.01 \mathrm{Bb}$ & $2.25 \pm 0.50 \mathrm{Aa}$ & $0.50 \pm 0.58 \mathrm{BCb}$ \\
Triplaris americana & $1.50 \pm 0.58 \mathrm{ABa}$ & $2.00 \pm 0.02 \mathrm{Aa}$ & $0.25 \pm 0.50 \mathrm{Cb}$ \\
No plant & $2.00 \pm 0.82 \mathrm{ABa}$ & $2.00 \pm 0.82 \mathrm{Aa}$ & $1.75 \pm 0.96 \mathrm{ABa}$ \\
CV (\%) & & 37.3 & \\
\hline
\end{tabular}

Averages followed by the same lowercase letter do not differ by Tukey's test at $5 \%$ significance for the herbicidal factor. Means followed by the same capital letter do not differ according to the Scott-Knott grouping criterion at $5 \%$ significance for the species. CV: Coefficient of variation.

In some cases, there may be benefits to the accumulation of biomass in host plants if there is a harmful effect of the herbicide on microorganisms in the rhizosphere (Kalia and Gosal, 2011). Some microorganisms immobilize nutrients and may temporarily impair plant growth (Hobbie, 2015). In this study, less mycorrhizal colonization was observed in roots under the effect of herbicides (see Figure 2). In this manner, the herbicide would contribute to a greater availability of nutrients in the soil solution, thereby increasing the nutrient supply to plants.

On the other hand, T. americana was sensitive to both herbicides, showing a decrease in the total biomass accumulation. The lower biomass of the trees in soil containing atrazine could probably be attributed to the harmful effect of the herbicide after inhibiting the electron flow of photosystem II (Nakka et al., 2017). This inhibition generates a high energetic state that promotes the formation of reactive oxygen species (Triantaphylidès and Havaux, 2009), resulting in chlorosis and necrosis of the leaf tissue. Sulfentrazone promotes the accumulation of protoporphyrinogen in the chloroplast, leading to the disruption of the lipid cell membrane (Dayan and Watson, 2011), causing damage to leaf tissues, and biomass reduction in sensitive plants.

With respect to differences among species, the anatomical conditions of plants influence the movement of herbicides in tissues, and there is enormous variability among them (Bailey et al., 2003). Consequently, differences were observed between forest species treated with atrazine and sulfentrazone. Finally, it is worth noting that atrazine and sulfentrazone, in their commercial doses, are herbicides recommended for the control of pre-emergence herbaceous plants or seedlings, which are different from the tree species seedlings used in the experiment.

The greater rhizospheric colonization by mycorrhizal fungi in I. edulis can be explained by the ability of this species to tolerate the herbicide and the phytoremediation of soils with sulfentrazone residues (Santos et al., 2020). Some microorganisms can use the compounds of this degradation as an energy source for their growth and, consequently, increase colonization. Faced with a xenobiotic in the rhizosphere, some plants release exudates capable of encouraging microbial growth in the area. On the other hand, M. gardneriana, T. ciliata, and T. hirta are not referred to in the literature as sulfentrazone degraders. Herbicides can be toxic and inhibit the growth of microorganisms (Botelho et al., 2012), as observed in the colonization of soy by mycorrhizal fungi (Vieira et al., 2007).

Rhizospheric colonization by AMFs is greatly influenced by the presence of atrazine or sulfentrazone in the soil and by the plant species. AMFs are stimulated in the presence of the contaminant, and the stimulus is related to the herbicide dose. At high concentrations of atrazine in the soil, the establishment of AMFs may overlap with rhizospheric bacterial growth. Additionally, contamination by atrazine in the rhizosphere may favor the synthesis of phosphate-solubilizing enzymes and dehydrogenases (Huang et al., 2009). Sulfentrazone impairs the mycorrhizal colonization process in some tree species (Silva et al., 2014). The lower mycorrhizal colonization observed in T. hirta was inversely related to the higher biomass of this plant growing in soil with atrazine (see Figure 1). Thus, it is likely that the herbicide harmed the group of rhizospheric microorganisms, thus, consequently, partially favoring the accumulation of biomass by T. hirta.

The number of AMF spores in rhizospheric soil was more related to the tree species than to the herbicide. However, it was observed that atrazine decreased the number of spores in the rhizosphere of S. parahyba and $M$. gardneriana, in relation to other plants. On the other hand, sulfentrazone did not influence the number of spores. Spore production by AMFs is closely associated with the group of plants to which they belong (Aguilar-Trigueros et al., 2019). The observation of the effect of atrazine on the number of spores can also be associated with the amount of this herbicide in the solution. The dose of atrazine applied was 6.6 times higher than that of sulfentrazone.

The basal respiration rate of the soil is related to the $\mathrm{CO}_{2}$ emitted from the respiration processes by the aerobic microorganisms present, predominantly in the rhizospheric region. Changes in values, such as those observed being higher in I. edulis, M. gardneriana, and T. americana, under the effect of sulfentrazone do not necessarily suggest a positive effect. In situations where the microbial biomass 
decreases with an increase in the basal respiration rate, it can be suggested that there is unsustainability in the activity that led to such occurrence, which, in this case, are sulfentrazone residues. On the other hand, if the biomass has not changed, or even increased, it could be suggested that the herbicide promoted greater carbon allocation through the degradation of this compound, which is positive. This same effect can be observed if the $\mathrm{CO}_{2}$ rate has decreased, as observed for S. parahyba, T. ciliata, and T. hirta, under the effect of sulfentrazone, as long as the microbial biomass does not change or increase.

A stress value less than 0.2 of the non-metric multidimensional scaling means that the representation obtained is strong and easily interpretable (Blaud et al., 2015), and that the two dimensions are sufficient to accurately reflect the differences (Schütte et al., 2008). The multivariate analysis allowed us to group the species that were not treated with herbicides with M. gardneriana, S. parahyba, and T. ciliata treated with atrazine and S. parahyba and T. ciliata treated with sulfentrazone, which indicates the existence of a similar behavior even under stress caused by herbicides. This demonstrates greater tolerance for these species and a less intense effect on the functionality of their microbiological indicators. The effect of herbicides is also evidenced by the absence of plants without herbicides outside the group.

The use of plant species as herbicide indicators is common (Batista et al., 2018). Cucumis sativus (cucumber) is used as a bioindicator plant for atrazine and sulfentrazone residues because it is highly sensitive to these herbicides (Dourado Júnior et al., 2017; Araújo et al., 2019). The higher the concentrations of herbicides in the soil, the lower the count of live plants that explore the soil with their roots and perform photosynthetic processes. In the present study, the number of live cucumber plants was lower in the pots where T. hirta was grown with atrazine and sulfentrazone. The biomass of T. hirta increased when it was intoxicated by herbicides. Possibly, this greater biomass enabled the release of allelopathic compounds in the soil, as plants of this genus are allelopathic.

The number of live cucumber plants after cultivation in T. americana rhizosphere soil was also lower. Triplaris americana plants were damaged by sulfentrazone and accumulated little biomass. This result could probably be attributed to the herbicides that remained in the soil and intoxicated the cucumber plants, owing to their great residual power (Shaner, 2014).

The number of cucumber plants in pots with herbicides where trees were not grown was equivalent to that in pots where the trees were grown, except for T. americana grown in soil with sulfentrazone. As the pots without plants remained as such for 120 days, with the soil at $70 \%$ of the field capacity and with good physical and chemical conditions (see Table 2), it is likely that the residual herbicides were reduced by processes independent of the plants, especially the degradation by microorganisms favored by soil fertility (Parte et al., 2017). The process of the natural attenuation of sulfentrazone in the soil may be more important than phytoremediation, which depends on the plant and the soil (Santos et al., 2019).
Another possible justification is the movement of the herbicide in the soil; when present via the subsoil, the herbicide is distributed evenly owing to its physical characteristics and the processes of water movement (Honeycutt, 2018). With regard to pots with plants, the water absorption process by the seedlings, concentrates the herbicide in the rhizosphere region (place of soil removal for the bioassay). Additionally, as the phytoremediation process depends on plant species and other variables, it is possible that $T$. americana seedlings absorb the herbicide and return part of it to the rhizospheric soil through root exudation (Ghanizadeh and Harrington, 2017).

Finally, the ability of $I$. edulis to tolerate pollutants in the soil was demonstrated. This species showed greater mycorrhizal colonization after being treated with sulfentrazone, however, none of its other characteristics was affected by the herbicides. This species is strongly recommended for populating riparian forest areas and downstream agricultural fields. The results of this study verified that AMFs may be related to the remedial capacity of this and other tree species. Therefore, this association should be considered in the selection of species for phytoremediation programs.

This work shows that the activity indicators of the arbuscular mycorrhizal fungi of trees subjected to atrazine and sulfentrazone treatments were affected and the effects were dependent on both the product and the species.

\section{Acknowledgements}

To "Conselho Nacional de Desenvolvimento Científico e Tecnológico (CNPq)”, “Coordenação de Aperfeiçoamento de Pessoal de Nível Superior (CAPES)", "Fundação de Amparo à Pesquisa do Estado de Minas Gerais (FAPEMIG)" and Food Machinery Corporation (FMC - project 01/2019) for financial support.

\section{References}

AGUILAR-TRIGUEROS, C.A., HEMPEL, S., POWELL, J.R., CORNWELL, W.K. and RILLIG, M.C., 2019. Bridging reproductive and microbial ecology: a case study in arbuscular mycorrhizal fungi. The ISME Journal, vol. 13, no. 4, pp. 873-884. http://dx.doi.org/10.1038/ s41396-018-0314-7. PMid:30504896.

ANDERSON, T.H. and DOMSCH, K.H., 2010. Soil microbial biomass: the eco-physiological approach. Soil Biology E Biochemistry, vol. 42, no. 12, pp. 2039-2043. http://dx.doi.org/10.1016/j. soilbio.2010.06.026.

ARAÚJO, F.R., DOS SANTOS, J.B., FERREIRA, E.A., CABRAL, C.M., LAIA, M., SILVA, D.V. and FREITAS, S.M., 2019. Selection of arboreal species to compose and remedy riparian forests next to agricultural areas. Ecological Engineering, vol. 131, pp. 9-15. http://dx.doi.org/10.1016/j.ecoleng.2019.02.023.

ATHER NADEEM, M., ABBAS, T., TANVEER, A., MAQBOOL, R., ZOHAIB, A. and SHEHZAD, M.A., 2017. Glyphosate hormesis in broadleaved weeds: a challenge for weed management. Archives of Agronomy and Soil Science, vol. 63, no. 3, pp. 344-351. http:// dx.doi.org/10.1080/03650340.2016.1207243.

BAILEY, W.A., HATZIOS, K.K., BRADLEY, K.W. and WILSON, H.P., 2003. Absorption, translocation, and metabolism of sulfentrazone 
in potato and selected weed. Weed Science, vol. 51, no. 1, pp. 32-36. http://dx.doi.org/10.1614/0043-1745(2003)051[0032:AT AMOS]2.0.CO;2.

BARCHANSKA, H., BABILAS, B., GLUZICKA, K., ZRALEK, D. and BARANOWSKA, I., 2014. Rapid determination of mesotrione, atrazine and its main degradation products in selected plants by MSPD - HPLC and indirect estimation of herbicides phytotoxicity by chlorophyll quantification. International Journal of Environmental Analytical Chemistry, vol. 94, no. 2, pp. 99-114. http://dx.doi.org/10.1080/03067319.2013.791977.

BATISTA, P.F., COSTA, A.C., MEGGUER, C.A., LIMA, J.S., SILVA, F.B., GUIMARÃES, D.S., ALMEIDA, G.M. and NASCIMENTO, K.J.T., 2018. Pouteria torta: a native species of the Brazilian Cerrado as a bioindicator of glyphosate action. Brazilian Journal of Biology = Revista Brasileira de Biologia, vol. 78, no. 2, pp. 296-305. http:// dx.doi.org/10.1590/1519-6984.07416. PMid:29069161.

BELZ, R.G. and DUKE, S.O., 2014. Herbicides and plant hormesis. Pest Management Science, vol. 70, no. 5, pp. 698-707. http:// dx.doi.org/10.1002/ps.3726. PMid:24446388.

BENVENUTO, F., MARÍN, J.M., SANCHO, J.V., CANOBBIO, S., MEZZANOTTE, V. and HERNÁNDEZ, F., 2010. Simultaneous determination of triazines and their main transformation products in surface and urban wastewater by ultra-high-pressure liquid chromatography-tandem mass spectrometry. Analytical and Bioanalytical Chemistry, vol. 397, no. 7, pp. 2791-2805. http://dx.doi.org/10.1007/s00216-010-3712-x. PMid:20658761.

BERRUTI, A., LUMINI, E., BALESTRINI, R. and BIANCIOTTO, V., 2016. Arbuscular mycorrhizal fungi as natural biofertilizers: let's benefit from past successes. Frontiers in Microbiology, vol. 6, pp. 1559. http://dx.doi.org/10.3389/fmicb.2015.01559. PMid:26834714.

BETHLENFALVAY, G.J., PACOVSKY, R.S. and BROWN, M.S., 1981. Measurement of mycorrhizal infection in soybeans. Soil Science Society of America Journal, vol. 45, no. 5, pp. 871-875. http:// dx.doi.org/10.2136/sssaj1981.03615995004500050009x.

BLAUD, A., DIOUF, F., HERRMANN, A.M. and LERCH, T.Z., 2015. Analysing the effect of soil organic matter on bacterial communities using T-RFLP fingerprinting: different methods, different stories? Biology and Fertility of Soils, vol. 51, no. 8, pp. 959-971. http://dx.doi.org/10.1007/s00374-015-1041-0.

BOTELHO, R.G., FROES, C.M. and SANTOS, J.B., 2012. Toxicity of herbicides on Escherichia coli growth. Brazilian Journal of Biology = Revista Brasileira de Biologia, vol. 72, no. 1, pp. 141-146. http:// dx.doi.org/10.1590/S1519-69842012000100016. PMid:22437394.

CABRAL, C.M., SANTOS, J.B., FERREIRA, E.A., MACHADO, V.M., PEREIRA, I.M., SILVA, D.V. and SOUZA, M.F., 2017. Tolerance to the herbicide clomazone and potential for changes of forest species. Bioscience Journal, vol. 33, no. 4, pp. 897-904. http:// dx.doi.org/10.14393/BJ-v33n4a2017-36750.

CAO, B., ZHANG, Y., WANG, Z., LI, M., YANG, F., JIANG, D. and JIANG, Z., 2018. Insight into the variation of bacterial structure in atrazinecontaminated soil regulating by potential phytoremediator: Pennisetum americanum (L.) K. Schum. Frontiers in Microbiology, vol. 9, pp. 864. http://dx.doi.org/10.3389/fmicb.2018.00864. PMid:29780374.

CHELLAIAH, D. and YULE, C.M., 2018. Effect of riparian management on stream morphometry and water quality in oil palm plantations in Borneo. Limnologica, vol. 69, no. 2, pp. 72-80. http://dx.doi.org/10.1016/j.limno.2017.11.007.

CLARKE, K.R., 1993. Non-parametric multivariate analyses of changes in community structure. Australian Journal of Ecology, vol. 18, no. 1, pp. 117-143. http://dx.doi.org/10.1111/j.1442-9993.1993. tb00438.x.

CULMAN, S.W., GAUCH, H.G., BLACKWOOD, C.B. and THIES, J.E., 2008. Analysis of T-RFLP data using analysis of variance and ordination methods: a comparative study. Journal of Microbiological Methods, vol. 75, no. 1, pp. 55-63. http://dx.doi. org/10.1016/j.mimet.2008.04.011. PMid:18584903.

DAYAN, F.E. and WATSON, S.B., 2011. Plant cell membrane as a marker for light dependent and light independent herbicide mechanisms of action. Pesticide Biochemistry and Physiology, vol. 101, no. 3 , pp. 182-190. http://dx.doi.org/10.1016/j.pestbp.2011.09.004.

DOURADO JÚNIOR, S., NUNES, E.S., MARQUES, R.P., ROSSINO, L.S., QUITES, F.J., SIQUEIRA JÚNIOR, J.R. . and MORETO, J.A., 2017. Controlled release behavior of sulfentrazone herbicide encapsulated in Ca-ALG microparticles: preparation, characterization, mathematical modeling and release tests in field trial weed control. Journal of Materials Science, vol. 52, no. 16, pp. 9491-9507. http://dx.doi.org/10.1007/s10853-017-1103-9.

DRAGIĆEVIĆ, M., PLATIŠA, J., NIKOLIĆ, R., TODOROVIĆ, S., BOGDANOVIĆ, M., MITIĆ, N. and SIMONOVIĆ, A., 2013. Herbicide phosphinothricin causes direct stimulation hormesis. DoseResponse, vol. 11, no. 3, pp. 1-17. http://dx.doi.org/10.2203/ dose-response.12-039.Simonovic. PMid:23983663.

DRUILLE, M., CABELLO, M.N., OMACINI, M. and GOLLUSCIO, R.A., 2013. Glyphosate reduces spore viability and root colonization of arbuscular mycorrhizal fungi. Applied Soil Ecology, vol. 64, pp. 99-103. http://dx.doi.org/10.1016/j.apsoil.2012.10.007.

FARIA, A.T., SOUZA, M.F., JESUS PASSOS, A.B.R., SILVA, A.A., SILVA, D.V., ZANUNCIO, J.C. and ROCHA, P.R.R., 2018. Tebuthiuron leaching in three Brazilian soils as affected by soil pH. Environmental Earth Sciences, vol. 77, no. 5, pp. 214. http://dx.doi.org/10.1007/ s12665-018-7285-X.

GERDEMANN, J.W. and NICOLSON, T.H., 1963. Spores of mycorrhizal Endogone species extracted from soil by wet sieving and decanting. Transactions of the British Mycological Society, vol. 46, no. 2, pp. 235-244. http://dx.doi.org/10.1016/S00071536(63)80079-0.

GHANIZADEH, H. and HARRINGTON, K.C., 2017. Non-target site mechanisms of resistance to herbicides. Critical Reviews in Plant Sciences, vol. 36, no. 1, pp. 24-34. http://dx.doi.org/10.10 80/07352689.2017.1316134.

GÓMEZ, L., CONTRERAS, A., BOLONIO, D., QUINTANA, J., OÑATESÁNCHEZ, L. and MERINO, I., 2019. Phytoremediation with trees. Advances in Botanical Research, vol. 89, pp. 281-321. http://dx.doi.org/10.1016/bs.abr.2018.11.010.

GUSTAFSON, D.I., 1989. Groudwater ubiquity score: a simple method for assessing pesticide leachibility. Environmental Toxicology and Chemistry, vol. 8, no. 4, pp. 339-357. http:// dx.doi.org/10.1002/etc.5620080411.

HOBBIE, S.E., 2015. Plant species effects on nutrient cycling: revisiting litter feedbacks. Trends in Ecology E Evolution, vol. 30, no. 6, pp. 357-363. http://dx.doi.org/10.1016/j.tree.2015.03.015. PMid:25900044.

HONEYCUTT, R., 2018. Mechanisms of pesticide movement into ground water. Milton: CRC Press. http://dx.doi. org/10.1201/9781351074346.

HUANG, H., ZHANG, S., WU, N., LUO, L. and CHRISTIE, P., 2009. Influence of Glomus etunicatum/Zea mays mycorrhiza on atrazine degradation, soil phosphatase and dehydrogenase activities, and soil microbial community structure. Soil Biology E' Biochemistry, vol. 41, no. 4, pp. 726-734. http://dx.doi. org/10.1016/j.soilbio.2009.01.009.

JARDIM BOTÂNICO DO RIO DE JANEIRO - JBRJ, 2020 [viewed 9 January 2020]. Algas, fungos e plantas [online]. Rio de Janeiro: JBRJ. Available from: htp://floradobrasil.jbrj.gov.br/reflora/listaBrasil/ ConsultaPublicaUC/ResultadoDaConsultaNovaConsulta. do\#CondicaoTaxonCP

JONER, E.J. and LEYVAL, C., 2009. Phytoremediation of organic pollutants using mycorrhizal plants: a new aspect of rhizosphere 
interactions. In: E. LICHTFOUSE, M. NAVARRETE, P. DEBAEKE, S. VÉRONIQUE and C. ALBEROLA, eds. Sustainable agriculture. Dordrecht: Springer. pp. 885-894. http://dx.doi.org/10.1007/97890-481-2666-8_54.

KALIA, A. and GOSAL, S.K., 2011. Effect of pesticide application on soil microorganisms. Archives of Agronomy and Soil Science, vol. 57, no. 6, pp. 569-596. http://dx.doi.org/10.1080/03650341003787582.

MARTINELLI, L.A., NAYLOR, R., VITOUSEK, P.M. and MOUTINHO, P., 2010. Agriculture in Brazil: impacts, costs, and opportunities for a sustainable future. Current Opinion in Environmental Sustainability, vol. 2, no. 5-6, pp. 431-438. http://dx.doi. org/10.1016/j.cosust.2010.09.008.

NAKKA, S., GODAR, A.S., THOMPSON, C.R., PETERSON, D.E. and JUGULAM, M., 2017. Rapid detoxification via glutathione Stransferase (GST) conjugation confers a high level of atrazine resistance in Palmer amaranth (Amaranthus palmeri). Pest Management Science, vol. 73, no. 11, pp. 2236-2243. http:// dx.doi.org/10.1002/ps.4615. PMid:28500680.

NOURI, E., BREUILLIN-SESSOMS, F., FELLER, U. and REINHARDT, D., 2014. Phosphorus and nitrogen regulate arbuscular mycorrhizal symbiosis in Petunia hybrida. PLoS One, vol. 9 no. 6, e90841. http://dx.doi.org/10.1371/journal.pone.0090841. PMid:24608923.

PARTE, S.G., MOHEKAR, A.D. and KHARAT, A.S., 2017. Microbial degradation of pesticide: a review. African Journal of Microbiological Research, vol. 11, no. 24, pp. 992-1012. http:// dx.doi.org/10.5897/AJMR2016.8402.

PASSOS, A.B.R., FREITAS, M.A.M., TORRES, L.G., SILVA, A.A., QUEIROZ, M.E.L. and LIMA, C.F., 2013. Sorption and desorption of sulfentrazone in Brazilian soils. Journal of Environmental Science and Health. Part. B, Pesticides, Food Contaminants, and Agricultural Wastes, vol. 48, no. 8, pp. 646-650. http://dx.doi. org/10.1080/03601234.2013.777313. PMid:23638891.

PETERSON, M.A., MCMASTER, S.A., RIECHERS, D.E., SKELTON, J. and STAHLMAN, P.W., 2016. 2, 4-D past, present, and future: a review. Weed Technology, vol. 30, no. 2, pp. 303-345. http:// dx.doi.org/10.1614/WT-D-15-00131.1.

RAINBIRD, B., BENTHAM, R.H. and SOOLE, K.L., 2018. Rhizoremediation of residual sulfonylurea herbicides in agricultural soils using Lens culinaris and a commercial supplement. International Journal of Phytoremediation, vol. 20, no. 2, pp. 104-113. http:// dx.doi.org/10.1080/15226514.2017.1337070. PMid:28613079.

SANTOS, E., PIRES, F.R., FERREIRA, A.D., EGREJA FILHO, F.B., MADALÃO, J.C., BONOMO, R. and ROCHA JUNIOR, P.R., 2019. Phytoremediation and natural attenuation of sulfentrazone: mineralogy influence of three highly weathered soils. International Journal of Phytoremediation, vol. 21, no. 7, pp. 652-662. http://dx.doi.org/10.1080/15226514.2018.1556583 . PMid:30656954.

SANTOS, E.A., CORREIA, N.M., SILVA, J.R.M., VELINI, E.D., PASSOS, A.B.R.J. and DURIGAN, J.C., 2015. Herbicide detection in groundwater in Córrego Rico-SP watershed. Planta Daninha, vol. 33, no. 1, pp. 147-155. http://dx.doi.org/10.1590/S010083582015000100017.

SANTOS, E.A., SILVA FILHO, U.S.D., BARROSO, G.M., ROCHA, B.P.J.S. and POSSATO, E.L., 2020. Tolerance and remedial potential of trees submitted to atrazine and sulfentrazone in the rhizosphere. International Journal of Phytoremediation, vol. 22, no. 1, pp. 78-86. http://dx.doi.org/10.1080/15226514.2019.1644290. PMid:31364395.

SANTOS, N.M.C., COSTA, V.A.M., ARAÚJO, F.V., ALENCAR, T.B., RIBEIRO, V.H., OKUMURA, F., SIMEONE, M.L.F. and SANTOS, J.B., 2018. Phytoremediation of Brazilian tree species in soils contaminated by herbicides. Environmental Science and Pollution Research International, vol. 25, no. 27, pp. 27561-27568. http://dx.doi. org/10.1007/s11356-018-2798-0. PMid:30054835.
SCHÜTTE, U.M., ABDO, Z., BENT, S.J., SHYU, C., WILLIAMS, C.J., PIERSON, J.D. and FORNEY, L.J., 2008. Advances in the use of terminal restriction fragment length polymorphism (T-RFLP) analysis of 16S rRNA genes to characterize microbial communities. Applied Microbiology and Biotechnology, vol. 80, no. 3, pp. 365-380. http://dx.doi.org/10.1007/s00253-0081565-4. PMid:18648804.

SEQUINATTO, L., REICHERT, J.M., SANTOS, D.R., REINERT, D.J. and COPETTI, A.C.C., 2013. Occurrence of agrochemicals in surface waters of shallow soils and steep slopes cropped to tobacco. Química Nova, vol. 36, no. 6, pp. 768-772. http://dx.doi. org/10.1590/S0100-40422013000600004.

SHANER, D.L., 2014. Herbicide handbook of the Weed Science Society of America. Lawrence: Weed Science Society of America.

SILVA, E.E., DE AZEVEDO, P.H.S. and DE-POLLI, H., 2007. Determinação da respiração basal (RBS) e quociente metabólico do solo $\left(\mathrm{qCO}_{2}\right)$. Seropédica: Embrapa Agrobiologia.

SILVA, G.S., MELO, C.A.D., FIALHO, C.M.T., SANTOS, L.D.T., COSTA, M.D. and SILVA, A.A., 2014. Impact of sulfentrazone, isoxaflutole and oxyfluorfen on the microorganisms of two forest soils. Bragantia, vol. 73, no. 3, pp. 292-299. http://dx.doi. org/10.1590/1678-4499.0061.

SMITH, S.E. and SMITH, F.A., 2012. Fresh perspectives on the roles of arbuscular mycorrhizal fungi in plant nutrition and growth. Mycologia, vol. 104, no. 1, pp. 1-13. http://dx.doi.org/10.3852/11229. PMid:21933929.

THORNGREN, J.L., HARWOOD, A.D., MURPHY, T.M., HUFF HARTZ, K.E., FUNG, C.Y. and LYDY, M.J., 2017. Fate and risk of atrazine and sulfentrazone to nontarget species at an agriculture site. Environmental Toxicology and Chemistry, vol. 36, no. 5, pp. 1301-1310. http://dx.doi.org/10.1002/ etc.3664. PMid:27779324.

TREU, R. and FALANDYSZ, J., 2017. Mycoremediation of hydrocarbons with basidiomycetes-a review. Journal of Environmental Science and Health. Part. B, Pesticides, Food Contaminants, and Agricultural Wastes, vol. 52, no. 3, pp. 148-155. http://dx.doi.org/10.1080/0 3601234.2017.1261536. PMid:28121269.

TRIANTAPHYLIDÈS, C. and HAVAUX, M., 2009. Singlet oxygen in plants: production, detoxification and signaling. Trends in Plant Science, vol. 14, no. 4, pp. 219-228. http://dx.doi.org/10.1016/j. tplants.2009.01.008. PMid:19303348.

VIEIRA, R.F., SILVA, C.M.M. and SILVEIRA, A.P., 2007. Soil microbial biomass $C$ and symbiotic processes associated with soybean after sulfentrazone herbicide application. Plant and Soil, vol. 300, no. 1-2, pp. 95-103. http://dx.doi.org/10.1007/s11104007-9392-4.

VIERHEILIG, H., COUGHLAN, A.P., WYSS, U.R.S. and PICHÉ, Y., 1998. Ink and vinegar, a simple staining technique for arbuscularmycorrhizal fungi. Applied and Environmental Microbiology, vol. 64, no. 12, pp. 5004-5007. http://dx.doi.org/10.1128/ AEM.64.12.5004-5007.1998. PMid:9835596.

VOSÁTKA, M., RYDLOVÁ, J., SUDOVÁ, R. and VOHNÍK, M., 2006. Mycorrhizal fungi as helping agents in phytoremediation of degraded and contaminated soils. In: M. MACKOVA, D. DOWLING and T. MACEK, eds. Phytoremediation rhizoremediation. Switzerland: Springer. pp. 237-257. http:// dx.doi.org/10.1007/978-1-4020-4999-4_17.

ZALLES, V., HANSEN, M.C., POTAPOV, P.V., STEHMAN, S.V., TYUKAVINA, A., PICKENS, A., SONG, X., ADUSEI, B., OKPA, C., AGUILAR, R., JOHN, N. and CHAVEZ, S., 2019. Near doubling of Brazil's intensive row crop area since 2000. Proceedings of the National Academy of Sciences of the United States of America, vol. 116, no. 2, pp. 428-435. http://dx.doi.org/10.1073/ pnas.1810301115. 